\title{
METABOLOMICS UNRAVEL DIFFERENCES BETWEEN CAMEROON Dura AND DELI Dura OIL PALM (Elaeis guineensis Jacq.) GENETIC BACKGROUNDS AGAINST BASAL STEM ROT
}

\author{
ZAIN NURAZAH*; ABU SEMAN IDRIS*; KUSHAIRI, A; AMIRUDDIN MOHD DIN*; \\ OTHMAN ABRIZAH and UMI SALAMAH RAMLI*
}

\begin{abstract}
Metabolomics is emerging as a powerful tool for screening of metabolites in both phenotyping and diagnostic analyses in plants. Metabolomics coupled with multivariate statistical analysis has provided a fast and unbiased comparative investigation of the metabolite composition in oil palm root. Basal stem rot (BSR) caused by the white rot fungus, Ganoderma boninense is a common oil palm disease in south-east Asia. Little is known about the disease mechanism and there is yet no satisfactory treatment for it. Besides agronomic practice of reducing the disease inoculum in the field, breeding for resistance to the disease is probably the most practical control. This study investigated metabolomic differences in oil palm planting materials with varying susceptibility to G. boninense from Cameroon and Deli genetic backgrounds. Liquid chromatography-quadrupole/time-of-flight-mass spectrometry (LC-Q/TOF-MS) data was subjected to multivariate statistical analysis and discovered that the palms could be categorised into two clusters linked to Cameroon and Deli oil palms. Changes in metabolites involved in phenylpropanoid pathway and primary metabolism including shikimic acid, glucose and malic acid were observed. The comprehensive and unbiased strategy for metabolite data analysis presented here can be adopted to screen wider oil palm germplasm for those potentially useful for breeding BSR-resistant palms.
\end{abstract}

Keywords: metabolomics, oil palm, BSR, Ganoderma boninense, LC-Q/TOF-MS.

Date received: 8 December 2016; Sent for revision: 14 December 2016; Received in final form: 2 March 2017; Accepted: 26 April 2017.

\section{INTRODUCTION}

Oil palm (Elaeis guineensis Jacq.) is an important oil crop in South-east Asia. In 2015, the world palm oil production reached 62.56 million tonnes (Oil World Annual, 2016), of which the Malaysian share was 19.28 million tonnes (MPOB, 2016). However, the palm is susceptible to various pests and diseases, the most serious in South-east Asia being basal stem rot

\footnotetext{
Malaysian Palm Oil Board, 6 Persiaran Institusi, Bandar Baru Bangi, 43000 Kajang,

Selangor, Malaysia.

E-mail: umi@mpob.gov.my
}

(BSR) by the white rot fungus, Ganoderma boninense (Cooper et al., 2011; Paterson et al., 2009; Idris et al., 2004a). Integrated control using chemical and biological means has been tried against the disease (Sundram, 2013; Sundram et al., 2008; Susanto et al., 2005; Idris et al., 2004b) but with at most limited success. Resistance to BSR is only partial (Idris et al., 2004a) and the disease management is complicated by the presence of different species of Ganoderma with various degrees of aggressiveness with the dominant species varying in different localities (Wong et al., 2012).

The disease triangle - the concept of a disease caused by the trinity of a pathogen attacking a 
susceptible host in a favourable environment (Agrios, 2005) - is a paradigm in plant pathology (Francl, 2007). A disease can therefore be prevented by eliminating any one (or more) of the trinity (Ravichandra, 2013). In the triangle, the host plant resistance is the only practicable measure for human manipulation to control the disease (Cooper et al., 2001; Verdier et al., 1997). Albeit some specificity of resistant varieties of oil palm progenies has been claimed, no clear-cut gene relationship with resistance has been demonstrated and no so-called resistant line to BSR is known (Cooper et al., 2011). Though, screening oil palm progenies for partial resistance to $G$. boninense has been done (Breton et al., 2006; Idris et al., 2004a), and field observation in North Sumatra suggests Deli origin (from both Malaysia and Indonesia) to be more susceptible than African origin (Durand-Gasselin et al., 2005), indicating possible genetic resistance in some populations (Cooper et al., 2011).

Yet, the study of resistance to BSR will require resistant oil palm lines and a reliable method to screen for the resistance is a requisite for the work. Metabolomics approaches which enable the assessment of a broad range of metabolites have been reported to have boundless advantage in both phenotyping and diagnostic analysis in plants (Fernie and Schauer, 2009). Metabolomics depends principally on the methodologies and instrumentations for large-scale analysis of diverse metabolic characteristics and highly complex mixtures of metabolites (Hong et al., 2016). Mass spectrometry (MS) hyphenated with analytical technologies such as liquid chromatography (LC) or/and gas chromatography (GC) enables robust identification and quantification of broad range of metabolites. Metabolomics is an important tool in genomics-assisted selection in crops (Fernie and Keurentjes, 2011). Metabolomic analysis contributes significantly to the understanding of the relation between genotype and metabolic outputs by tackling key network components (Toubiana et al., 2013). The candidate genes for specific metabolites which have potential targets for quality improvement and uncovering the mechanisms of complex agronomic traits have been discovered (Gong et al., 2013). In oil palm, because of the long gestation for the disease symptoms to appear - by which time the palm may already be dying - any method to obtain early evidence of the disease will be invaluable in studying the disease progression, and proteomics may well be a way to do so (Jeffery Daim et al., 2015; Syahanim et al., 2013). However, little has been done on oil palm metabolites to provide the background for screening work (Nurazah et al., 2013). Using the metabolomics perspective to study genetic variation may deepen our understanding of plant biology as reported in wheat (Triticum aestivum), thale cress (Arabidopsis thaliana) and rice (Oryza sativa) (Hill et al., 2015; Routaboul et al., 2012; Matsuda et al., 2012).

Moreover, there are diverse metabolites in the oil palm root that may contribute to the palm resistance to disease, both preformed, e.g., phytoanticipin, and inducible, e.g., phytoalexin (Diabate et al., 2009). Several metabolites have been found associated with oil palm-Ganoderma interactions. Chelidonic acid was found in leaf of oil palm artificially-infected with G. boninense (Dzulkafli et al., 2015). Accumulation of phenolic acids, especially syringic acid, in oil palm root inoculated with $G$. boninense suggests their anti-fungal properties against the pathogen (Chong et al., 2012). Sterols and tocopherols were also detected using gas chromatography-mass spectrometry (GC-MS) in the roots of oil palm artificially infected with $G$. boninense (Nusaibah et al., 2011). In previous research, oil palm resistance to vascular wilt (Fusarium oxysporum) is due to the production of phenolic compounds in the roots of the infected palm, and their presence can therefore be an indicator of the disease infection (Diabate et al., 2009).

Recent advances of instrumentation and informatics tool have facilitated the simultaneous analysis of a large number of metabolites. This study was conducted to explore the metabolite profiling using available parental palm materials (based on progeny testing against Ganoderma) at this particular time via liquid chromatographyquadrupole/time-of-flight-mass spectrometry (LCQ/TOF-MS) on oil palm from Cameroon (African) and Deli genetic backgrounds to uncover the constituents/metabolites that potentially confer the palm resistance/susceptibility to BSR according to the genetic background. The LC-Q/TOF-MS detection, annotation, interpretation and workflow may afford a way to distinguish resistant planting materials based on genetic backgrounds at the metabolite level.

\section{MATERIALS AND METHODS}

\section{Chemicals}

Acetonitrile and acetic acid for high performance liquid chromatography (HPLC) and methanol for metabolite extraction were purchased from Merck, Germany, and shikimic acid standard ( $\geq 90 \%$ ) from Sigma-Aldrich, USA. All solvents used were HPLC grade. Water was purified by a Milli-Q system (Milipore, USA).

\section{Sample Collection and Preparation}

Roots from 26-year old oil palm were taken from MPOB Research Station Kluang, Johor, Malaysia. Twelve palms from two different genetic backgrounds with possible sources of 
genetic resistance were selected based on previous selection for resistance to BSR, ranging from partial resistant to the most susceptible (Idris et al., 2004a). Six biological replicates from Cameroon dura were (\#0.219/126, $0.219 / 405, \quad 0.219 / 441,0.219 / 496$, $0.219 / 549$ and $0.219 / 637$ ), siblings of the partially resistant Cameroon pisifera (\#0.219/1371), and the other six biological replicates from the siblings of the susceptible Deli dura (\#0.212/642) - (\#0.212/67, $0.212 / 68,0.212 / 69,0.212 / 71$ and $0.212 / 75)$, all without visible symptoms of Ganoderma infection. Healthy parental palms without any visible symptoms of BSR were selected based on similar age and planting location. The root tissues were harvested in the morning from 9 to 11 am by cutting the primary root. The primary roots, which spread either horizontally or descend into the soil, were harvested by digging around the palm at least 15 $\mathrm{cm}$ from the stem base. The secondary, tertiary and quaternary roots attached to the primary roots were removed. Care was taken not to damage the root. The primary roots were cut, cleaned of clinging soil and immediately frozen in liquid nitrogen before grinding to a fine powder in a mortar with pestle. The samples were kept at $-80^{\circ} \mathrm{C}$ until use.

\section{Metabolite Extraction}

Metabolite extraction was performed according to Ferracane et al. (2010) with minor modifications. Five $\mathrm{ml} 80 \%$ (v/v) aqueous methanol was added to $500 \mathrm{mg}$ frozen root tissue powder in a Falcon tube. The root metabolites were extracted by sonication in an ultrasonic bath for $30 \mathrm{~min}$ and centrifugation at $3000 \mathrm{rpm}$ for $15 \mathrm{~min}$ at $25^{\circ} \mathrm{C}$. The resultant clear supernatant was collected and dried under a nitrogen stream before reconstituting in $3 \mathrm{ml}$ Milli-Q water. The extract was filtered through a $0.2 \mu \mathrm{m}$ cellulose acetate syringe filter and an aliquot of 150 $\mu \mathrm{l}$ was subjected to LC-MS analysis. The extraction was performed in three technical replicates.

\section{LC-Q/TOF-MS Analysis}

Metabolite analysis was performed using the Ultimate 3000 HPLC system with standard autosampler and photodiode array detector (Thermo Scientific, USA). The chromatographic separation was achieved on a Reversed-Phase Acclaim PolarAdvantage II column (C18 4.6 × 250 $\mathrm{mm}$ length, $5 \mu \mathrm{m}$ particle size) (Thermo Scientific, USA) at $37^{\circ} \mathrm{C}$ with gradient elution programme of $1.0 \mathrm{ml} \mathrm{min}-1$ flow rate and $5 \mu 1$ injection volume. The mobile phase consisted of: (A) water containing $0.1 \%$ $(\mathrm{v} / \mathrm{v})$ acetic acid, and $(\mathrm{B})$ acetonitrile containing $0.1 \%$ $(\mathrm{v} / \mathrm{v})$ acetic acid. The gradient applied started at 5\% $\mathrm{B}$ and increased linearly to $25 \% \mathrm{~B}$ in $45.5 \mathrm{~min}$. The column was washed for $5 \mathrm{~min}$ and equilibrated for 4 min to minimise carry-over between the injections.
A blank water injection was applied in-between the sample injections. The HPLC system was coupled to a mass detector-quadrupole/time-of-flight (Q/ TOF) MS with electrospray ionisation (ESI) interface operating in negative ion mode and controlled by the HyStar software (BrukerDaltonics, Germany). The effluent from the HPLC column was set at 1.0 $\mathrm{ml} \mathrm{min}^{-1}$ and reduced using a ' $\mathrm{T}$ ' type splitter before introduction into the MS (split ratio 1:4). The flow arriving at the detector was $250 \mu 1 \mathrm{~min}^{-1}$. Nitrogen was used as nebulising gas at 4.1 bar and 9.0 litres $\mathrm{min}^{-1}$ flow rate. The temperature and voltage of the capillary were set at $200^{\circ} \mathrm{C}$ and $+3.5 \mathrm{kV}$, respectively. The full scan covered the mass range from 50-1000 $m / z$.

\section{Data Analysis and Multivariate Statistics}

The accurate mass data of the molecular ions were processed through the DataAnalysis 3.4 software which provides a list of possible elemental formulas using the Generate-MolecularFormula (GMF) Editor (BrukerDaltonics, Germany). The GMF Editor uses a CHNO algorithm which provides the standard functionalities, such as minimum/ maximum elemental range, electron configuration and ring-plus double bond equivalents, as well as a comparison of the theoretical with measured isotope patterns (Sigma value) for increased confidence in the suggested molecular formula (BrukerDaltonics Technical Note No. 008, Molecular Formula Determination Under Automation). Corresponding structures were searched for in public databases (PubChem, KEGG, Chemspider) through Compound Crawler (BrukerDaltonics, Germany). Further identification using MetFrag (http:/ / msbi. ipb-halle.de/MetFrag/) was performed which provided in silico fragmentation (Wolf et al., 2010) for confirmation of the structural identity. The unsupervised multivariate statistics, principle component analysis (PCA), was performed using the ProfileAnalysis 2.0 software (BrukerDaltonics, Germany). The extraction of compounds was done (prior to the statistical analysis) using FindMolecularFeatures (FMF) for data reduction and comprehensive detection of all compounds in the LC-MS run. The LC-MS data were prepared for PCA using a bucketing approach to the FMF data [pairs of retention time (RT)- $m / z$ values formed and intensities assigned to each bucket $(=$ bucket value)], Pareto scaled so that each variable was centred and multiplied by $1 /\left(S_{d}\right)^{1 / 2}$. The LC-MS data was integrated from 1.8 to $50 \mathrm{~min}$ and 50.5 to 999.5 $\mathrm{m} / \mathrm{z}$ in time- and $m / z$-buckets using time alignment parameters in the advanced bucketing approach. Each datum was normalised to the sum of bucket values for an analysis. A statistical hypothesis test, t-test, was performed at a significance level of $<p$ 0.01 . For the supervised method, partial least squares 
(projections to latent structures)-discriminant analysis (PLS-DA) with scaling based on Pareto was performed using the SIMCA-P+ software (v. 12.0, Umetrics, Umea, Sweden). Means and standard deviations were calculated and the means compared with analysis of variance (ANOVA) at a significance level of $\mathrm{p}<0.05$.

\section{RESULTS AND DISCUSSION}

\section{Analysis of Metabolites by LC-Q/TOF-MS}

Metabolomics approach has provided a fast and unbiased comparative multivariate statistical analysis of the metabolite composition of oil palm samples. Methanol is generally used for extraction of various polar compounds but certain group of non-polar compounds are fairly soluble in methanol if not readily soluble (Kiran Kumar and Gowda, 2016) making it an effective extraction solvent. The aqueous methanolic extracts from the roots of 12 palms, six from each planting material, were not obviously different (Figure 1). In this study, the peaks were obtained from negative ionisation as it is more sensitive than positive ionisation, allowing more information to be gleaned on the compounds. Forty peaks were detected from the root samples. Figure 1 is a representative base peak chromatogram (BPC).

\section{Multivariate Statistical Analysis}

To determine the differences between samples, the metabolic phenotypes were examined by dimension reduction of the data sets based on their variance (Lindon et al., 2001) using an unsupervised method in PCA. PCA is used to evaluate similarities and differences between samples to simplify data management (Holmes and Antti, 2002). It had been used to identify prominent metabolites that differentiate resistant and susceptible rice and wheat cultivars to fungal and bacterial species (Browne and Brindle, 2007; Wu et al., 2012). The analysis shows clear differences where samples are clustered by their origin (Figure 2a). The first two principal components (PC) acquired were PC1 $(27.7 \%)$ and PC2 $(37.8 \%)$, in total representing $65.5 \%$ of the total variance in the scores plot. Cameroon dura was separated from Deli dura oil palm by

(a)

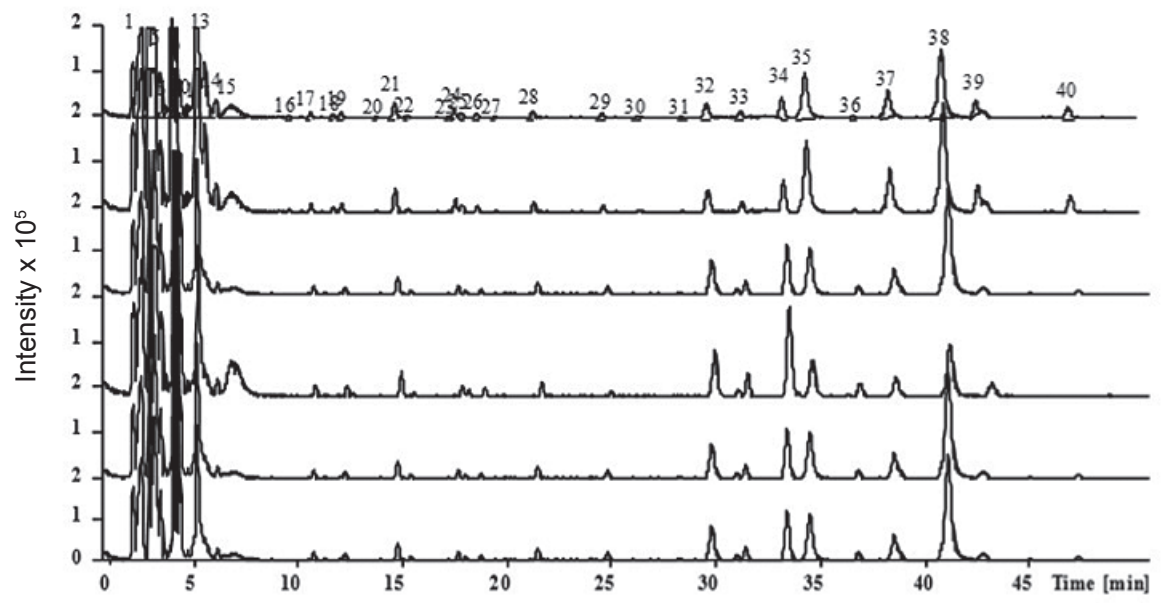

(b)

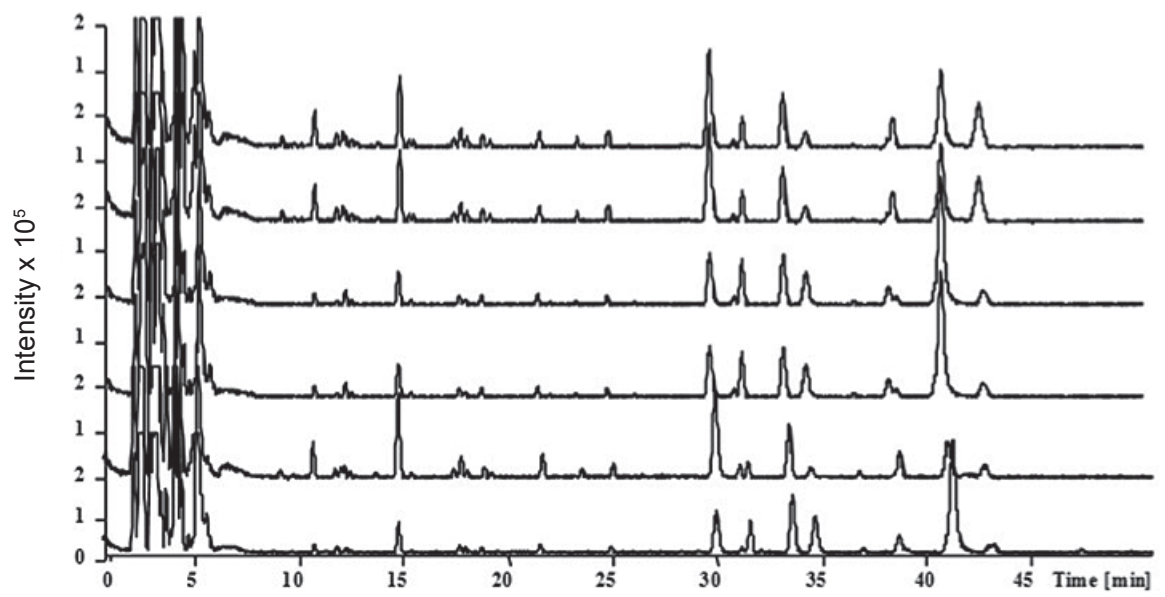

Figure 1. Representative liquid chromatography-mass spectrometry (LC-MS) chromatograms of oil palm root extracts.

(a) Deli dura and (b) Cameroon dura oil palm planting materials. 
(a)

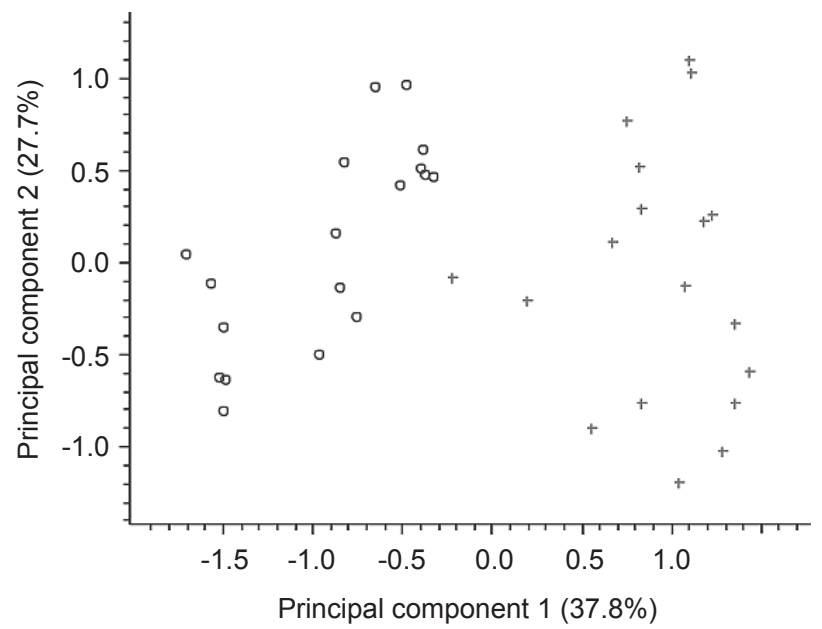

(b)

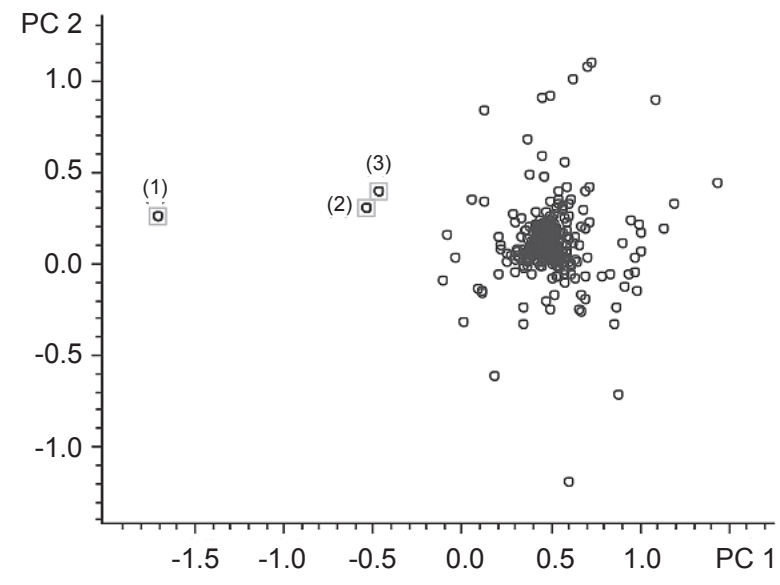

Figure 2. Score and loading plots of oil palm samples by principal component analysis (PCA), processed from mass spectrometry (MS) data in negative mode (o for Deli dura, + for Cameroon dura). (a) Score plots of principal component 1 (PC1) vs. principal component 2 (PC2), and (b) loading plots (1: shikimic acid, 2: malic acid, 3: glucose).

PC1. Validation of the PCA involved projection of a randomly selected test set of a sub-population of replicates into the remaining replicates (test set), where close superimposition of the test and training sets indicates highly reproducible data (Allwood et al., 2006). Each point in the PCA loadings plot (Figure $2 b$ ) represents a variable, including intensity and the corresponding mass-to-charge $(\mathrm{m} / \mathrm{z})$. Three metabolites distributed far from the mean centre of the plot corresponded to ions $\mathrm{m} / \mathrm{z}$ 173.0453, 179.0558 and 133.0143 and they are suggested as the differential metabolites in the oil palm groups. The distances between a series of ions in loadings plot stand for the contribution of the variables in differentiating between the classes in PCA components (Geng et al., 2013).

In order to understand the differences between the oil palm groups, and also the relation between the metabolites and the oil palm samples with different origin, a supervised method, i.e. partial least squares (projection to latent structures)discriminant analysis (PLS-DA) was implemented (Figure 3). The scores plot shows Cameroon dura separated from Deli dura oil palm by component 1 , which represented $50.46 \%$ of the total variance in the scores plot. By examining the corresponding loadings in the line plot of PLS-DA (Figure $3 b$ ), the metabolites greatly different in the oil palm samples were putatively assigned as shikimic acid $(m / z 173.0453)$, malic acid $(m / z 133.0143)$ and glucose $(m / z 179.0561)$, based on a collision-induced dissociation (CID) experiment which generated characteristic tandem mass spectrometry $\left(\mathrm{MS}^{2}\right)$ fragment ions that matched the metaboliteidentities (Table 2). The three metabolites were positively correlated to component 1 , thus suggesting their relation with the oil palms with different origin. They explained $68.39 \%, 35.71 \%$ and $37.56 \%$ of the variation, respectively. The compounds were much higher in Deli dura than Cameroon dura oil palm materials as shown in the variable line plot (Figure 4), and the variable importance in the projection (VIP) plot in Figure 5 further described the importance and relative contributions of the individual metabolites to the differences between the two oil palm groups. VIP-values $>1.0$ indicate the importance of the variables in the data set. The fold changes in concentration of the three most influential metabolites were significant at $p<0.01$ according to t-test (Table 1).

Model validation is one of the important aspects of supervised multivariate statistics. A permutation test is used for the validation, to compare the goodness of fit and predictive ability of the model (R2 and Q2) (Ali et al., 2012). In Figure 6, the PLS model was validated using the permutation test with 20 number of permutations. The R2 and Q2 were calculated using four components, which resulted in values of 0.64 and 0.50 , respectively. The model is considered valid where all the blue Q2values are lower than the original points to the right, the blue regression line of the Q2-points intersects the vertical axis (on the left) at, or below, zero and all green R2-values to the left are lower than the original points to the right (SIMCA-P+ software v. 12.0, Umetrics, Umea, Sweden).

Visualisation of the separation of oil palm materials Deli dura and Cameroon dura suggests different underlying metabolic mechanisms (Werth et al., 2010), possibly causing different susceptibilities of the palms to BSR. We postulate that the observed clustering supports the results from previous studies (Durand-Gasselin et al., 2005; Idris et al., 2004a) of highly susceptible progenies from dura $\mathrm{x}$ dura (Deli x Deli) materials, and the partially resistant ones from dura $\mathrm{x}$ pisifera [Zaire (now known as the 
Democratic Republic of the Congo) x Cameroon]. Screening for resistant palms seems the most practical approach for comprehensive molecular studies as it would eliminate as much as possible of the susceptible materials (Durand-Gasselin et al., 2005; McDonald and Linde, 2002; Miller et al., 1999). These results from metabolomics research will probably assist breeders to select diseaseresistant palms by integrating the accumulation and expression pattern of metabolites and genes of the pathways involving the particular metabolites. This will help in predicting the genes involved in particular processes (Saito and Matsuda, 2010). The accumulation of the resistance-related metabolites, hydroxycinnamic acid amides (HCAA), from the phenylpropanoid pathway observed in potato, was induced by Phytophtora infestans infection which can lead to the abundance of genes that catalyse the biosynthesis of the metabolites (Pushpa et al., 2014).

\section{Mass Spectrometric Characteristics and Comparison of Significant Metabolites in Oil Palm}

The significant metabolites were initially fingered by comparing their accurately measured mass values with their theoretical exact mass values and CID experimentation (Table 2). Besides the exact masses provided by the MS software, tandem MS $\left(\mathrm{MS}^{2}\right)$ spectra from the CID experiments provided additional hints on the structure of the compounds. MS and $\mathrm{MS}^{2}$ data were instrumental in the tentative identification of the metabolite constituents (Ma et al., 2013). Further confirmation and identification of the characteristic fragments of the ions were done using in silico fragmentation for computer-assisted identification of the metabolite mass spectra from MetFrag. In MetFrag, candidates with a good score of 1.0, or closest to 1.0, showed high structural similarity, or just different stereochemistry, and the in silico fragmentation matched with the KEGG compound library which describes a larger number of compounds (Wolf et al., 2010).

\section{Analysis of $m / z 173.0453$}

By comparing the accurately measured mass with the theoretical exact mass values, 173.0453 $\mathrm{m} / \mathrm{z}$ was tentatively identified as shikimic acid (Table 2). Further confirmation by $\mathrm{MS}^{2}$ analysis of the parent ion, $m / z 173.0453[\mathrm{M}-\mathrm{H}]-$, showed four major fragments - $m / z$ 155.0366, 137.0250, 111.0457 and 93.0340. Fragmentation of the $m / z 173.0453$ ion produced an $\mathrm{MS}^{2}$ base peak of $\mathrm{m} / \mathrm{z} 155.0366$ [M-H$\left.\mathrm{H}_{2} \mathrm{O}\right]$; , followed by $137.0250\left[\mathrm{M}-\mathrm{H}-2 \mathrm{H}_{2} \mathrm{O}\right]-, 111.0457$ $\left[\mathrm{M}-\mathrm{H}-\mathrm{H}_{2} \mathrm{O}-\mathrm{CO}_{2}\right]^{-}$and $93.0340 \quad\left[\mathrm{M}-\mathrm{H}-2 \mathrm{H}_{2} \mathrm{O}-\mathrm{CO}_{2}\right]^{-}$

TABLE 1. FOLD CHANGES IN CONCENTRATIONS OF THE THREE PUTATIVE METABOLITES

\begin{tabular}{lcc}
\hline$m / z$ (mass-to-charge) & Putative metabolite & $\begin{array}{c}\text { Fold changes* } \\
\text { (Deli } \text { dura/Cameroon } \text { dura) }\end{array}$ \\
\hline 173.0453 & Shikimic acid & 6.8781 \\
179.0558 & Glucose & 1.6034 \\
133.0143 & Malic acid & 1.9811
\end{tabular}

TABLE 2. MASS SPECTROMETRY (MS) AND MS² DATA FOR TENTATIVE IDENTIFICATION OF PROMINENT METABOLITES RESPONSIBLE FOR DIFFERENCES BETWEEN DELI Dura AND CAMEROON Dura OIL PALM

\begin{tabular}{ccccccc}
\hline No. $\begin{array}{c}t_{\mathrm{R}} \\
(\mathrm{min})\end{array}$ & $\begin{array}{c}\mathrm{m} / z \\
\text { measured }\end{array}$ & $\begin{array}{c}\mathrm{m} / z \\
\text { calculated }\end{array}$ & $\begin{array}{c}\text { Error } \\
(\mathrm{mDa})\end{array}$ & $\begin{array}{c}\text { Molecular } \\
\text { formula }\end{array}$ & $\begin{array}{c}\text { Putative } \\
\text { metabolites }\end{array}$ & $\begin{array}{c}\text { MS }{ }^{2} \\
\text { fragments }(\mathrm{m} / \mathbf{z})\end{array}$ \\
\hline 1. & 173.0453 & 173.0455 & 0.30 & $\mathrm{C}_{7} \mathrm{H}_{9} \mathrm{O}_{5}$ & Shikimic acid & 155.0366, \\
137.0250, \\
111.0457, \\
93.0340 \\
\end{tabular}

Note: $t_{\mathrm{R}}$ - retention time. $\mathrm{m} / \mathrm{z}$ - mass-to-charge ratio. 
(a)

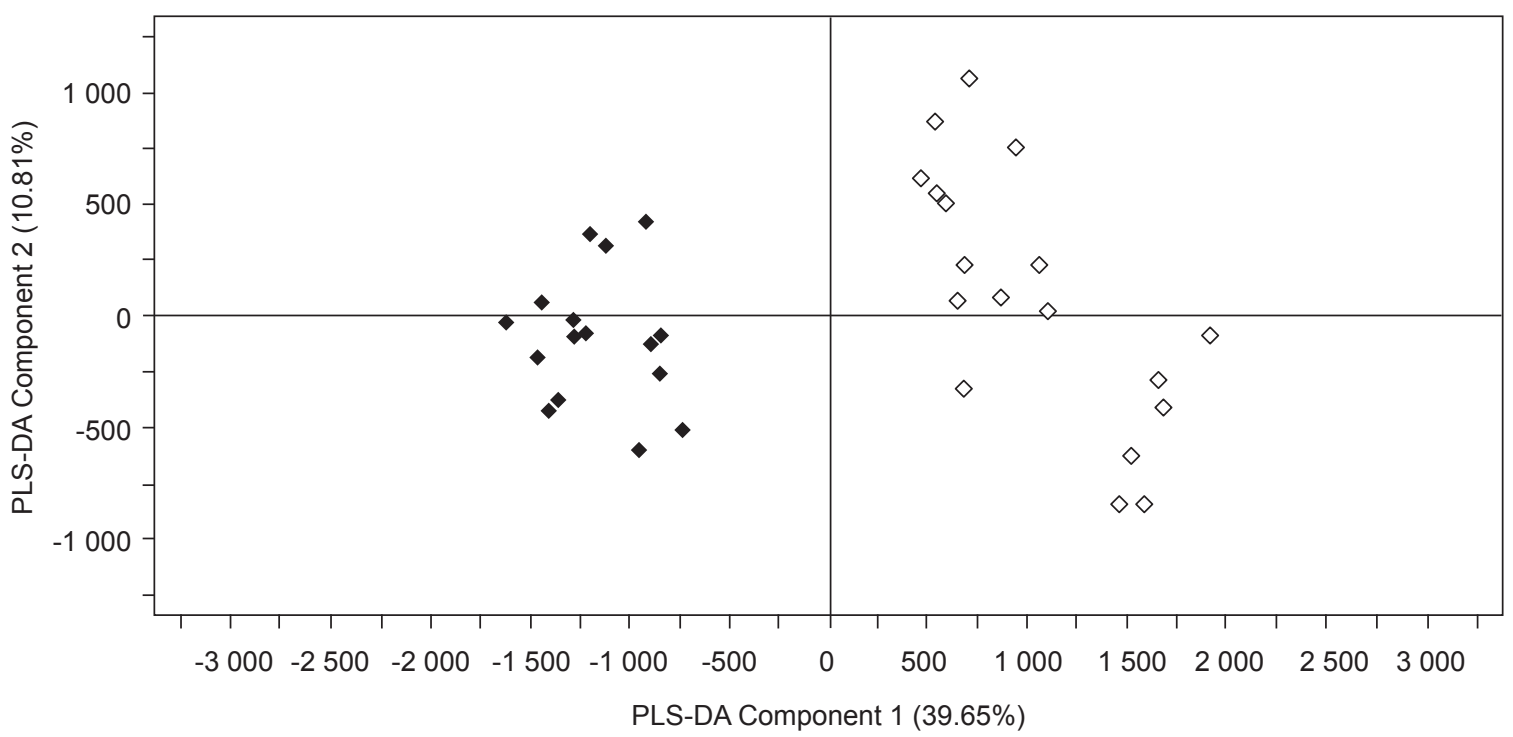

(b)

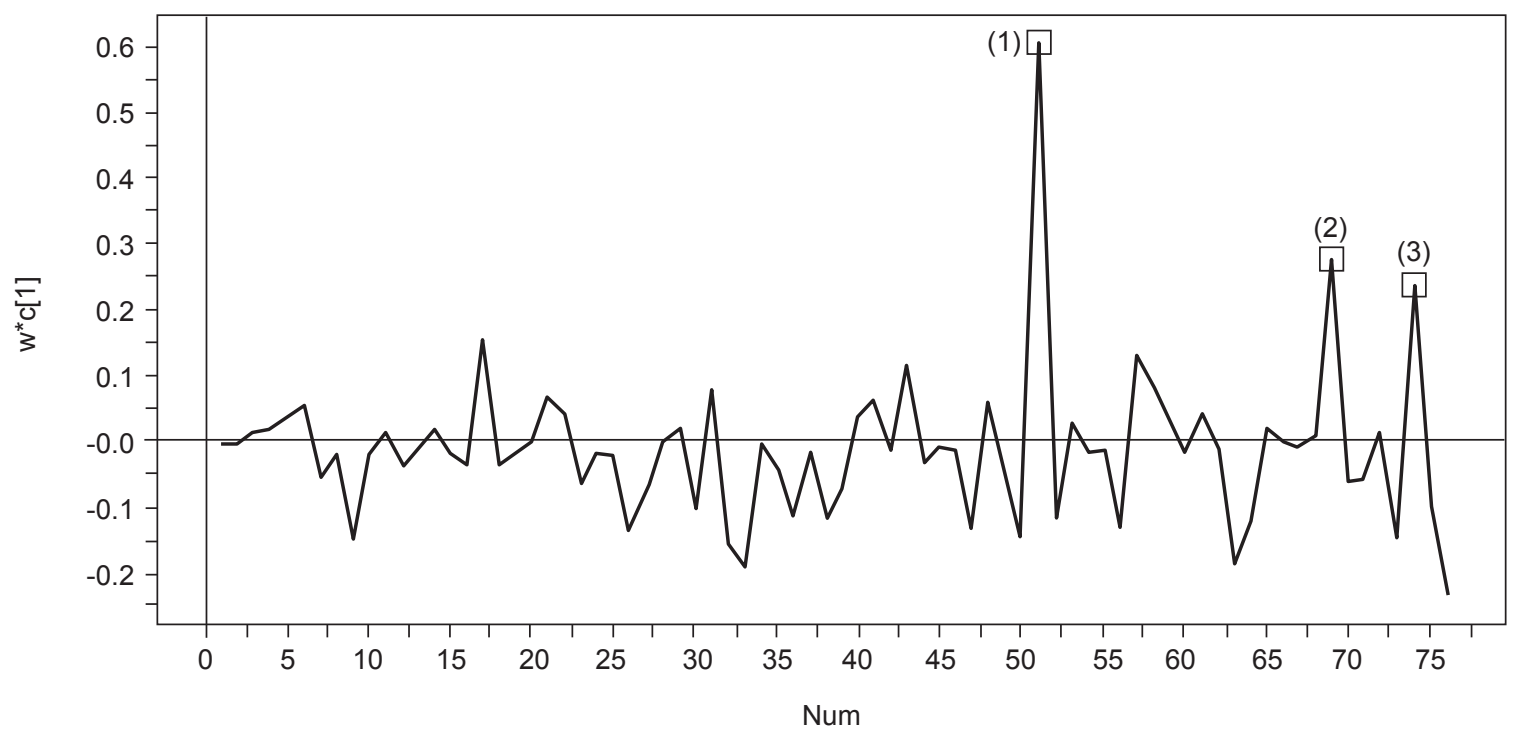

Figure 3. Score and loading line plots of oil palm samples by partial least squares-discriminant analysis (PLS-DA) from mass spectrometry (MS) data in negative mode ( $\diamond$ for Deli dura, for Cameroon dura). (a) Score plot of PLS-DA component 1 vs. PLS-DA component 2, and (b) loading line plot (1: shikimic acid, 2: malic acid, 3: glucose).

(Bylund et al., 2007). The annotated MS² spectrum of the measured peaks and corresponding fragments of the major signals are depicted in Figure 7. These data are consistent with the $\mathrm{MS}^{2}$ spectrum of the reference compound shown in Figure 8.

Shikimic acid, a plant phenolic, is a natural organic compound important as central intermediate in the phenylpropanoid pathway, an alternative route in the production of aromatic compounds, particularly the amino acids phenylalanine, tyrosine and tryptophan (Dewick, 2002). The phenylpropanoid pathway is a rich source of important secondary metabolites in plants, such as flavonoids, coumarins and lignans, which have been widely studied for their roles in the survival of plants, such as Arabidopsis (Fraser and Chapple,
2011). Lower shikimic acid in Cameroon dura oil palm material compared to Deli dura (Figure 4a) was observed. Primary metabolites are rapidly utilised to synthesise other preformed secondary metabolites as defence agents against microbial pathogens (Lattanzio et al., 2006). Shikimic acid accumulation has also been measured in determining glyphosate (herbicide) resistance in transgenic cotton (Pline et al., 2002).

\section{Analysis of $m / z 133.0143$}

Comparing the accurately measured with theoretical mass (Table 1), the ion at $\mathrm{m} / \mathrm{z} 133.0143$ $[\mathrm{M}-\mathrm{H}]^{-}$was tentatively identified as malic acid. $\mathrm{MS}^{2}$ fragments of the parent ion, which yielded three 
(a)

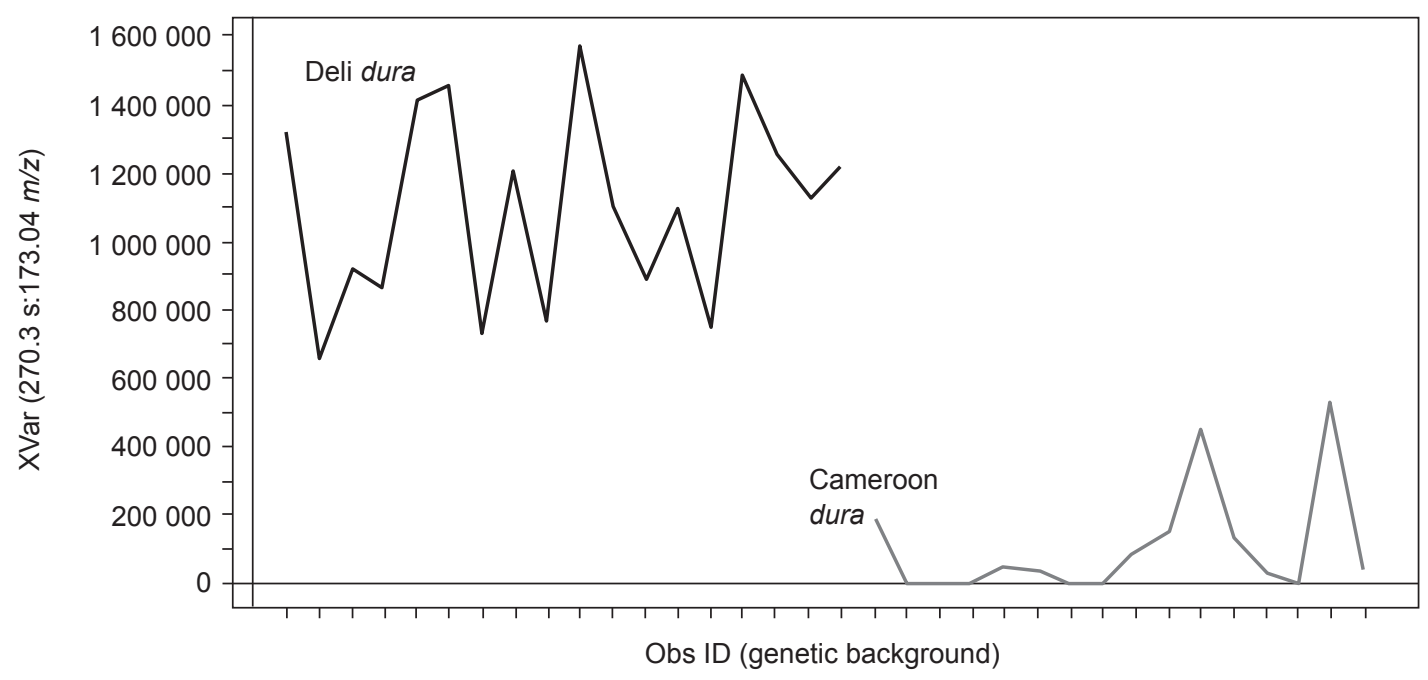

(b)

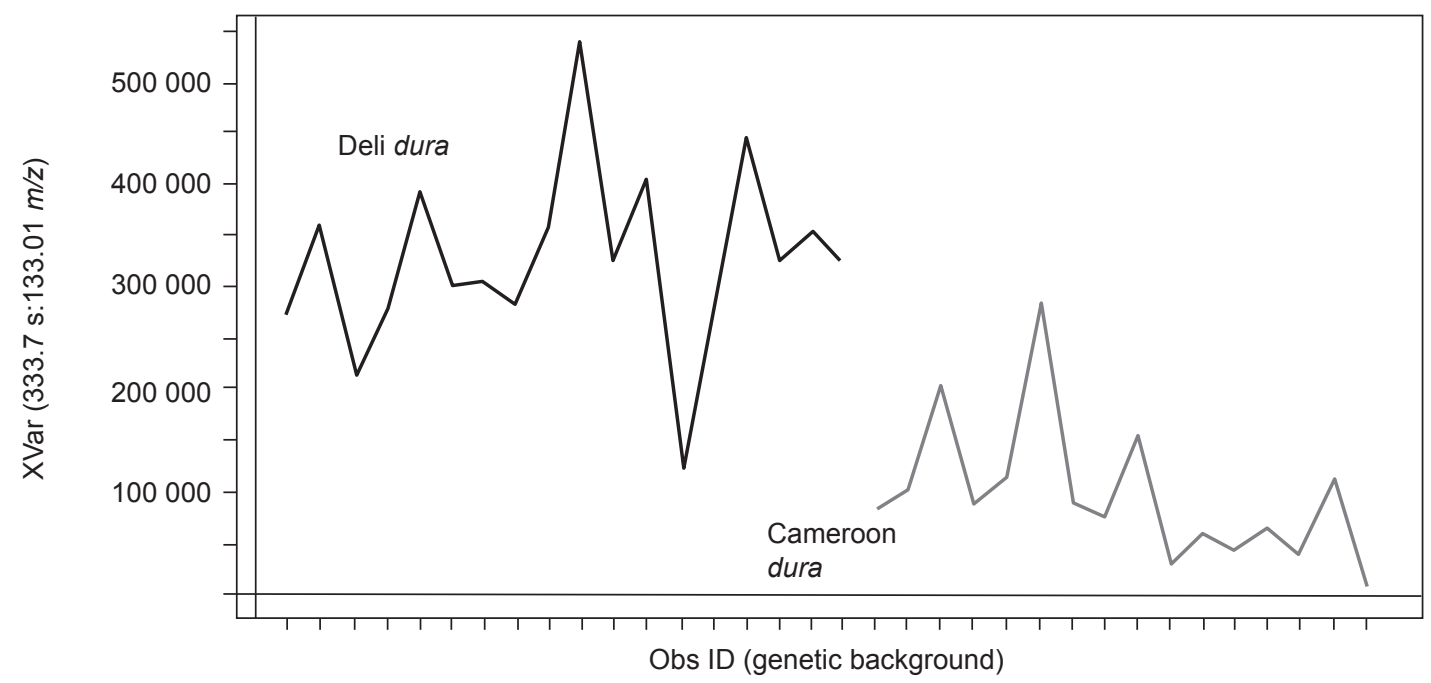

(c)

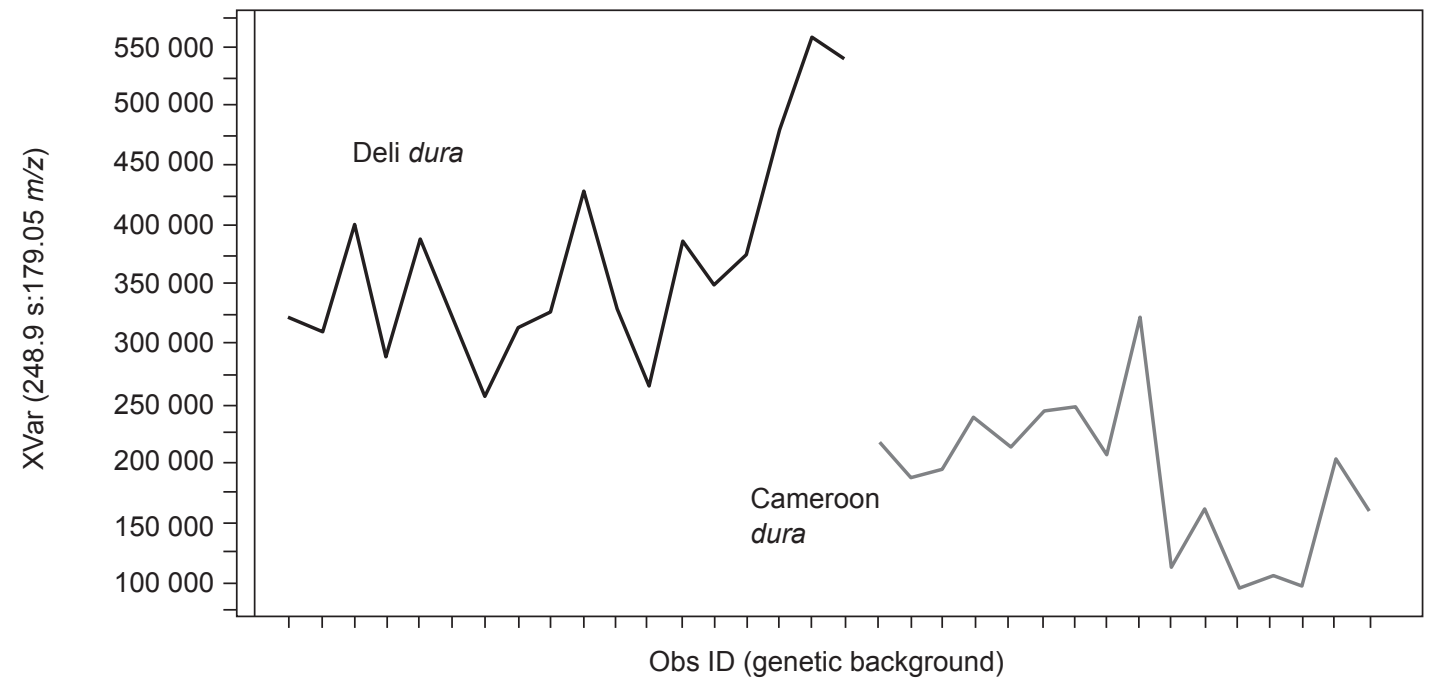

Figure 4. Variable line plots for three significant metabolites in Deli dura and Cameroon dura oil palm.

(a) Shikimic acid, (b) malic acid, and (c) glucose. 


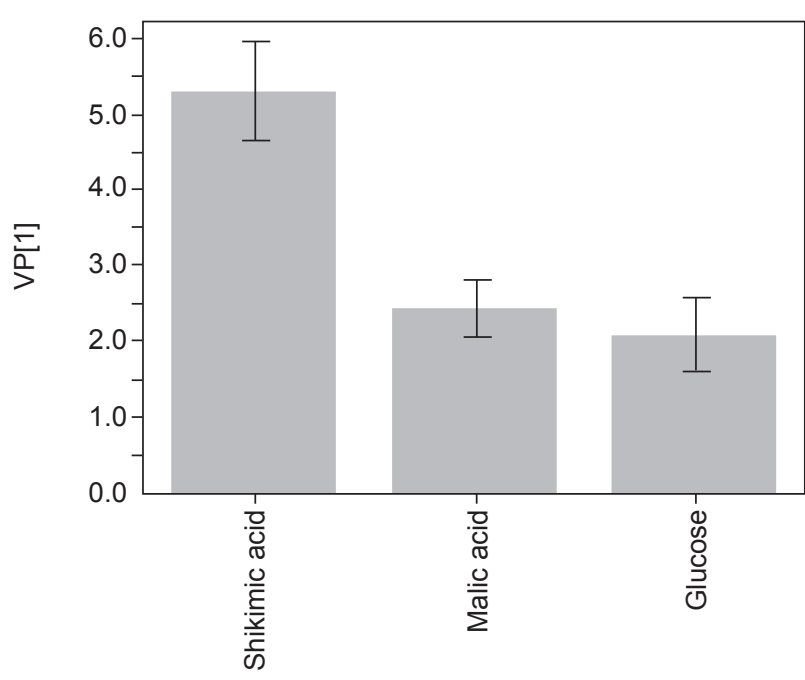

Figure 5. Variable importance in projection (VIP) plot showing relative contributions of shikimic acid, malic acid and glucose to differences between Deli dura and Cameroon dura oil palms. A variable (metabolite) is considered to respond significantly if the VIP value and its 95\% confidence interval exceeds 1. major product ions, showed characteristic fragments of malic acid at $\mathrm{m} / \mathrm{z} 115.0025\left[\mathrm{M}-\mathrm{H}_{-} \mathrm{H}_{2} \mathrm{O}\right]$ ], 89.0242 $\left[\mathrm{M}-\mathrm{H}-\mathrm{CO}_{2}\right]^{-}$and $71.0139\left[\mathrm{M}-\mathrm{H}-\mathrm{CO}_{2}-\mathrm{H}_{2} \mathrm{O}\right]^{-}$(Ng et al., 2004). The annotated $\mathrm{MS}^{2}$ spectrum of the measured peaks and corresponding fragments of the major signals are depicted in Figure 9.

Lower level of malic acid was observed in Deli compared to Cameroon dura (Figure 4b). Malic acid is a dicarboxylic acid, an intermediate in the primary metabolism, e.g., TCA cycle, of plants (Casati et al., 1999). Malic acid metabolism suggested that the acid may have a role in plant defence - there is increased expression of NADP-malic enzyme (one of the malic acid metabolising enzymes) in defencerelated deposition of lignin to provide NADPH and pyruvate for the shikimate pathway (for synthesis of aromatic amino acids, including phenylalanine) for lignin and flavonoid synthesis (Casati et al., 1999). Lignin component of oil palm woody tissue may be related to oil palm resistance as the white rot fungus will attack the lignin component and utilising

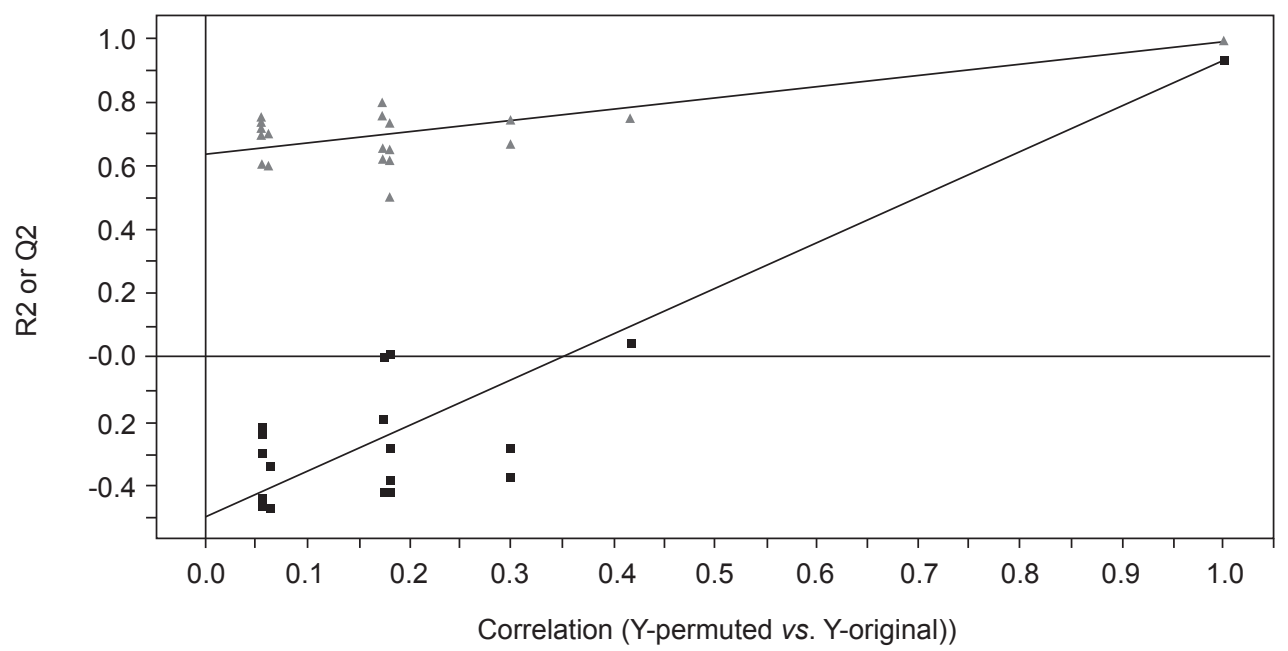

Figure 6. Permutation test for projections to latent structures-discriminant analysis (PLS-DA).

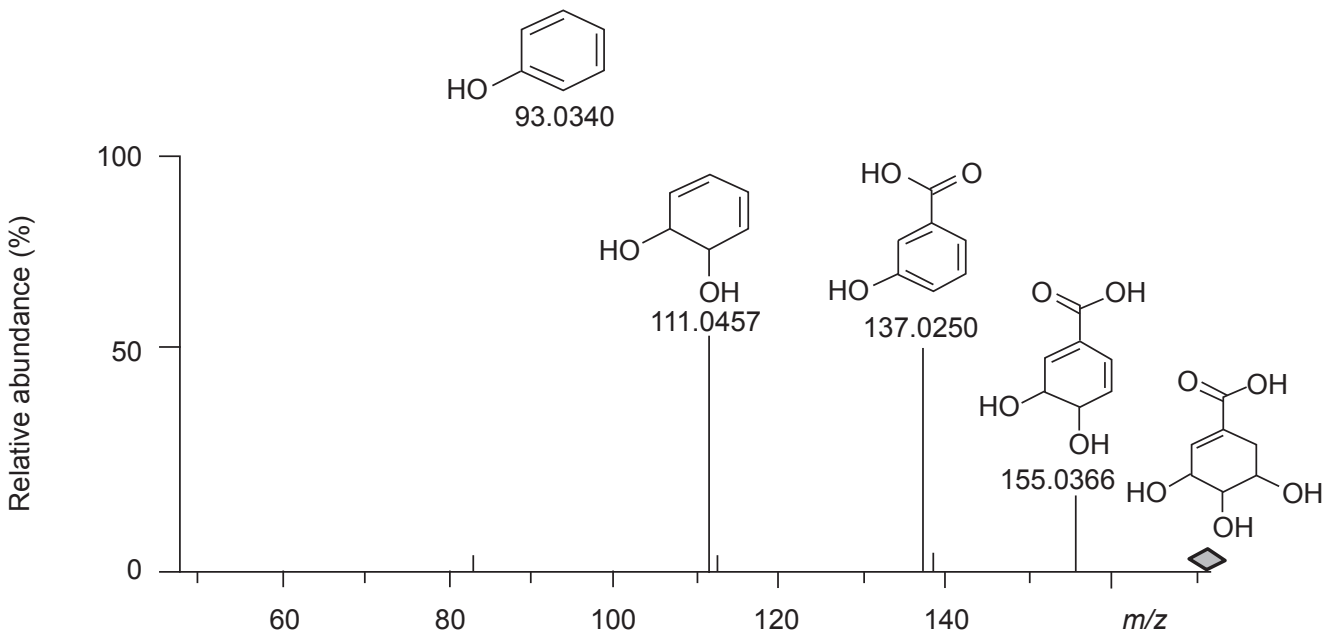

Figure 7. Annotated negative mode $\mathrm{MS}^{2}$ spectrum of shikimic acid $\left(173.0453 \mathrm{~m} / \mathrm{z}, \mathrm{C}_{7} \mathrm{H}_{9} \mathrm{O}_{5}\right)$ at collision energy $10 \mathrm{eV}$. 
(a)

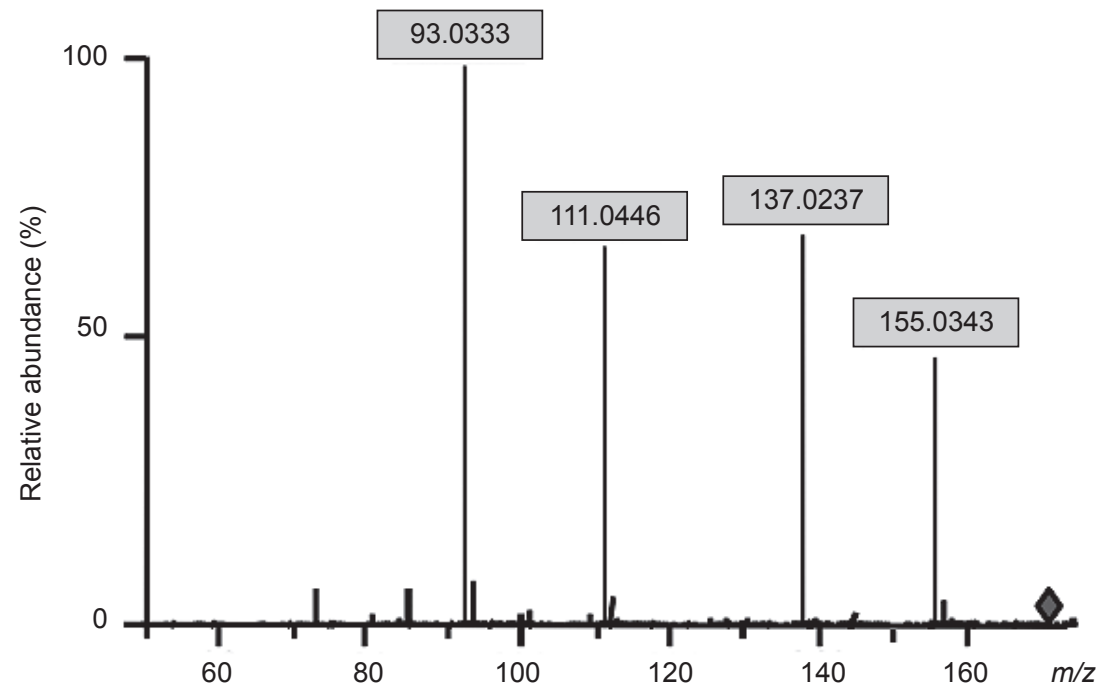

(b)

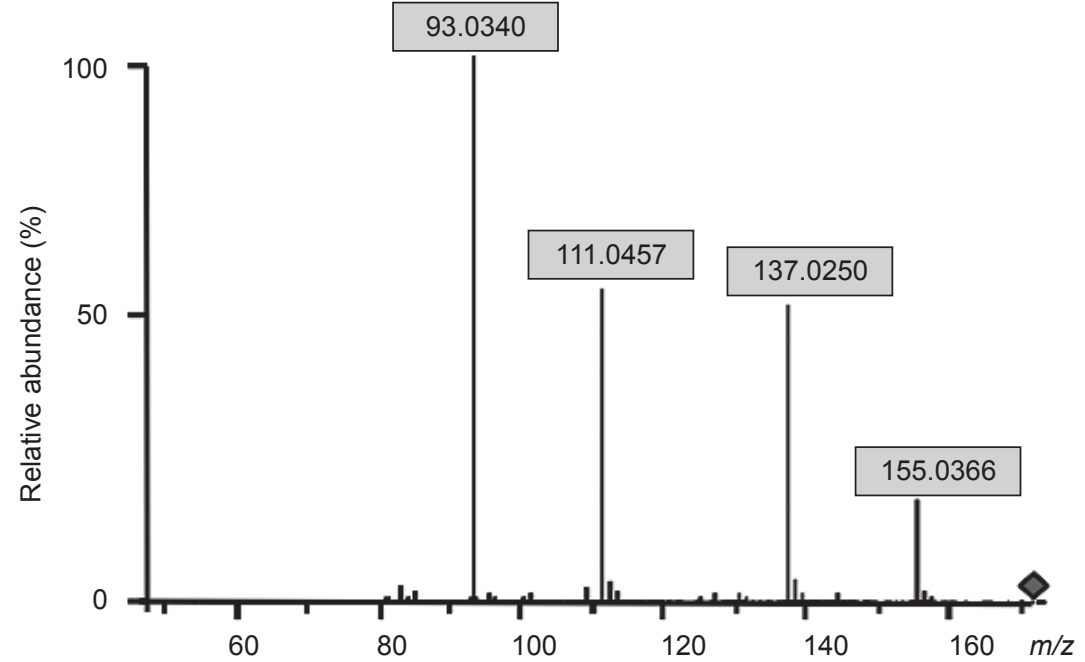

Figure 8. Similar $\mathrm{MS}^{2}$ spectra of (a) tentatively identified shikimic acid $(173.0453 \mathrm{~m} / \mathrm{z})$ and (b) shikimic acid reference standard.

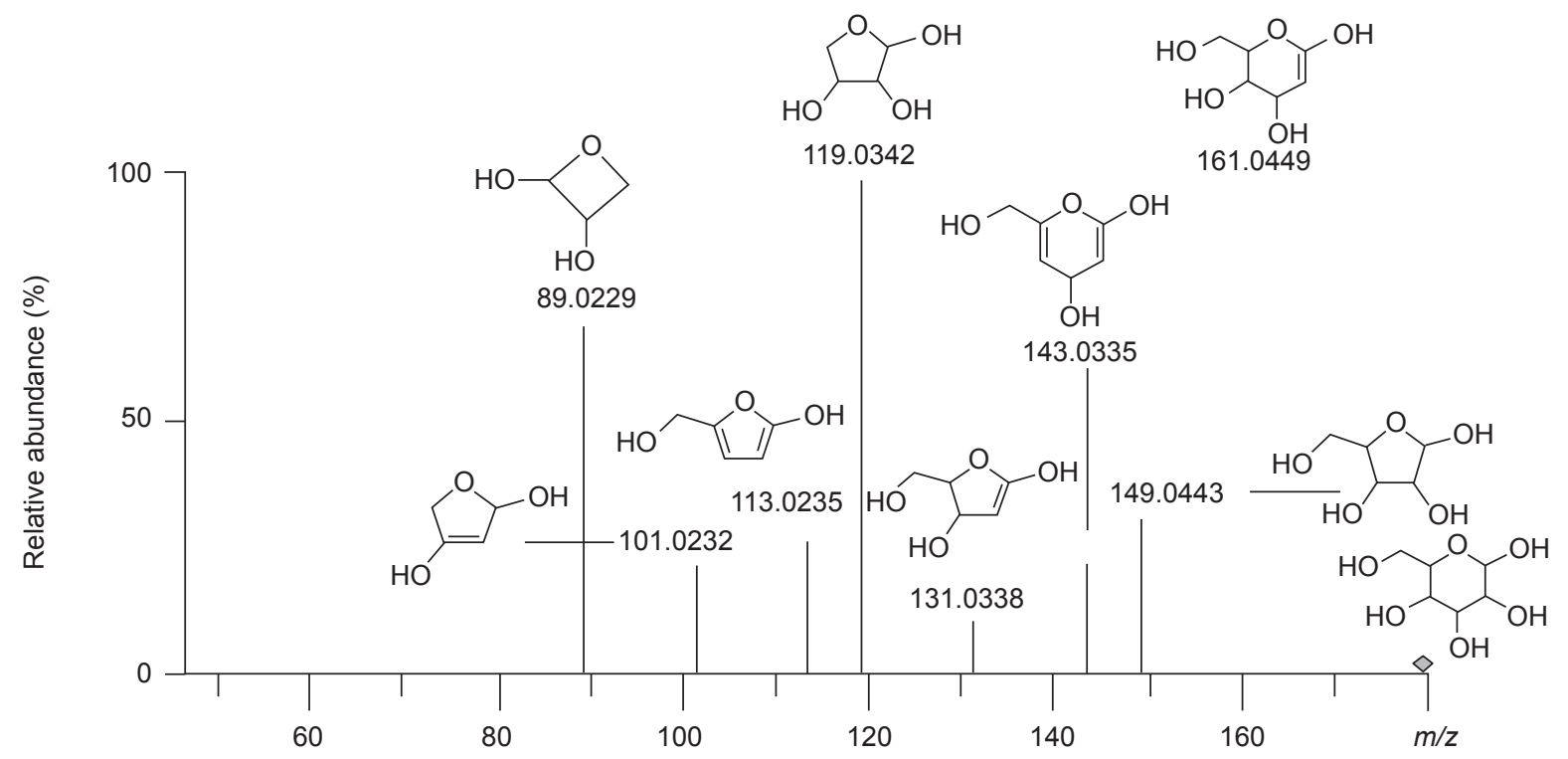

Figure 9. Annotated negative mode $\mathrm{MS}^{2}$ spectrum of glucose $\left(179.0558 \mathrm{~m} / \mathrm{z}, \mathrm{C}_{6} \mathrm{H}_{11} \mathrm{O}_{6}\right)$ at collision energy $10 \mathrm{eV}$. 
the cellulose in the tree (Paterson et al., 2009). However, there was also no correlation between lignin accumulation and oil palm susceptibility or tolerance to BSR (Fonguimgo et al., 2015).

\section{Analysis of $m / z 179.0558$}

Table 1 shows the tentative identification of $\mathrm{m} / \mathrm{z}$ 179.0558 as glucose based on the calculated and theoretical exact mass. $\mathrm{MS}^{2}$ analysis showed that the parent ion at $\mathrm{m} / \mathrm{z} 179.0558$ [M-H]- yielded eight fragment ions at $m / z 161.0449,149.0443,143.0335$, 131.0388, 119.0342, 113.0235, 101.0232 and 89.0229. The three product ions at $\mathrm{m} / \mathrm{z} 161.0449,149.0443$ and 143.0335 were formed from neutral losses of formaldehyde or water. The other five product ions - $m / z$ 131.0388, 119.0342, 113.0235, 101.0232 and 89.0229 were formed by neutral losses of $\mathrm{H}_{2} \mathrm{O}$ and $\mathrm{CH}_{2} \mathrm{O}$ (Taylor et al., 2005). They showed the characteristic of glucose, consistent with the data of Taylor et al. (2005). Figure 10 shows the annotated MS2 spectrum of the measured peaks and corresponding fragments of glucose for the major signals.

The higher glucose $\left(\mathrm{C}_{6} \mathrm{H}_{12} \mathrm{O}_{6}, \mathrm{~m} / z\right.$ 179.0558) in Deli (Figure $4 c$ ) than Cameroon dura materials was observed. Plant sugars, such as glucose, fructose and sucrose, are recognised signalling molecules in plants (Bolouri-Moghaddam et al., 2010; Rolland et al., 2006), besides their typical roles as carbon and energy sources (Koch, 2004). Sugars are involved in various metabolic pathways which may be of great importance in the plant (defence) stress response (Bolouri-Moghaddam and Van den Ende, 2012). In biotic stress caused by pathogenic fungi, the pathogens interfere with the metabolism of their host not only through the uptake of sugars for their own needs but also by disturbing the plant metabolism (Morkunas and Ratajczak, 2014). This suggests some dependence of the plant resistance on sugar levels. However, there are also reports on the importance of sucrose and hexose in resistance to fungal pathogens through the stimulation of phenylpropanoid metabolism (Gibertia et al., 2012; Morkunas et al., 2011; Forlani, 2010). In addition, the accumulation of hexose has been implicated in the expression of hexokinase that can sense soluble hexoses and regulate programmed cell death in plants (Kim et al., 2006). All these suggest sugar sensing in mediating carbohydrate metabolism and the defence response in plants (Bolton, 2009).

Plants which suffer frequent or serious damage produce a low constitutive chemical defence, and those rarely attacked relied predominantly on an induced defence (Wittstock and Gershenzon, 2002). In this metabolomics oil palm-BSR research, the oil palm disease resistance suggests a constitutive defence (Bell et al., 2010). Multiple metabolic pathways were observed, suggestive of their involvement in the palm disease resistance, which would require energy support from primary and secondary metabolism (Bolton, 2009).

\section{CONCLUSION}

The LC-Q/TOF-MS coupled with multivariate statistical analysis have demonstrated three metabolites from different classes of plant compounds - sugars, phenolic acids and organic acids - as potential oil palm metabolite markers that may assist breeders for the selection of partial resistance oil palms. Although the exact mechanism of BSR-tolerance is still unclear to support our observation that Cameroon materials are more resistant than Deli, this work is the first application of metabolomics to profile and identify differences in oil palm metabolites which may have potential to characterise/quantify the resistance together with other functional genomics studies. The established

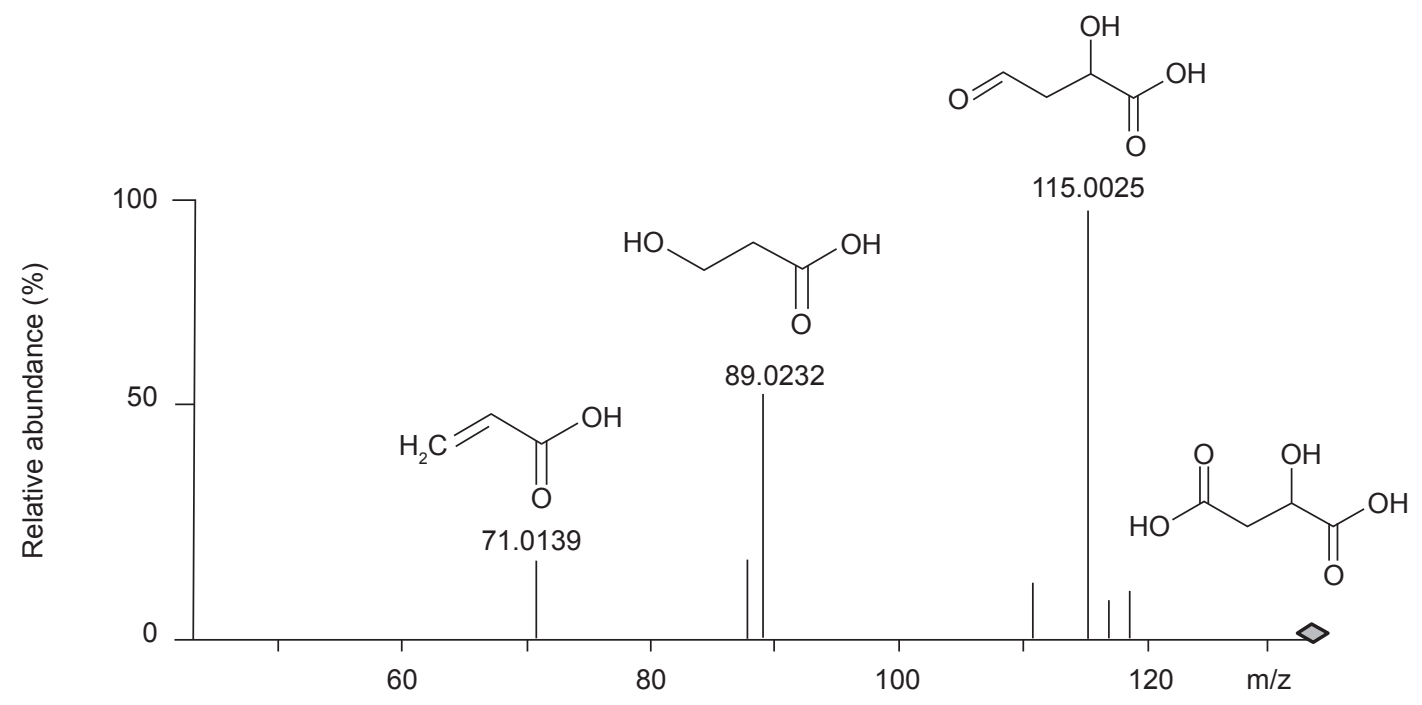

Figure 10. Annotated negative mode $\mathrm{MS}^{2}$ spectrum of malic acid $\left(133.0143 \mathrm{~m} / \mathrm{z}, \mathrm{C}_{4} \mathrm{H}_{5} \mathrm{O}_{5}\right)$ at collision energy $13 \mathrm{eV}$. 
LC-Q/TOF-MS-based metabolomics pipeline will be applied to oil palm inbred lines associated with BSR for future studies to further explore the relation between oil palm metabolome and resistance. Metabolomics represent as an important addition to the tools currently employed in genomics-assisted selection for oil palm resistance to BSR.

\section{ACKNOWLEDGEMENT}

The authors would like to thank the DirectorGeneral of MPOB for permission to publish this article, and also the staff of the Breeding and Quantitative Genetics Group of MPOB Kluang, Johor, Malaysia, Marhalil Marjuni, also from the Group for technical assistance and providing the oil palm samples. Also thanks to Dr Jaran Jai-Nhuknan from Bruker, Thailand and Dr Ow Saw Yen from Bruker, Malaysia for support and assistance. We would also like to extend our appreciation to Andy Chang Kwong Choong for his valuable comments on this manuscript. This research project was funded by MPOB (Establishment of Proteomics and Metabolomics Program - R005606000).

\section{REFERENCES}

AGRIOS, G N (2005). Plant Pathology. $5^{\text {th }}$ Edition. Elsevier-Academic Press, San Diego, CA.

ALI, K; IQBAL, M; KORTHOUT, H AA J; MALTESE, F; FORTES, A M; PAIS, M S; VERPOORTE, R and CHOI, Y H (2012). NMR spectroscopy and chemometrics as a tool for anti-TNF $\alpha$ activity screening in crude extracts of grapes and other berries. Metabolomics, 8: 1148-1161.

ALLWOOD, J W; ELLIS, D I; HEALD, J K; GOODACRE, R and MUR, L A J (2006). Metabolomic approaches reveal that phosphatidic acid and phosphatidyl glycerol phospholipids are major discriminatory non-polar metabolites in response by Brachypodium distachyon to challenge by Magnaporthe grisea. Plant J., 46: 351-368.

BELL, A A; HOWELL, C R and STIPANOVIC, R D (2010). Cotton host-microbe interactions. Physiology of Cotton (Stewart, J M; Oosterhuis, D M; Heitholt, J J and Mauney, J R eds). Springer, London. p. 187-205.

BOLOURI-MOGHADDAM, M R and VAN DEN ENDE, W (2012). Sugars and plant innate immunity. J. Experimental Botany: 1-10.

BOLOURI-MOGHADDAM, M R; LE ROY, K; XIANG, L; ROLLAND, F and VAN DEN ENDE, W (2010). Sugar signalling and antioxidant network connections in plant cells. FEBS J. 277: 2022-2037.
BOLTON, M D (2009). Primary metabolism and plant defense-fuel for the fire. Molecular PlantMicrobe Interactions, 22 (5): 487-497.

BRETON, F; HASAN, Y; HARIADI, S; LUBIS, Z and DE FRANQUIVILLE, H (2006). Characterization of parameters for the development of an early screening test for basal stem rot tolerance in oil palm progenies. J. Oil Palm Res. Special Issue: 24-36.

BROWNE, R A and BRINDLE, K M (2007). ${ }^{1} \mathrm{H}$ NMR-based metabolite profiling as a potential selection tool for breeding passive resistance against Fusarium head blight (FHB) in wheat. Molecular Plant Pathology, 8 (4): 401-410.

BYLUND, D; NORSTROM, S H; ESSEN, S A and LUNDSTROM, U S (2007). Analysis of low molecular mass organic acids in natural waters by ion exclusion chromatography tandem mass spectrometry. J. Chromatography A, 1176: 89-93.

CASATI, P; DRINCOVICH, M F; EDWARDS, G E and ANDREO, C S (1999). Malate metabolism by NADP-malic enzyme in plant defense. Photosynthesis Research, 61: 99-105.

CHONG K P; ATONG, M and ROSSALL, S (2012). The role of syringic acid in the interaction between oil palm and G. boninense, the causal agent of basal stem rot. Plant Pathology, 61: 953-963.

COOPER, R M; FLOOD, J and REES, R (2011). G. boninense in oil palm plantations: current thinking on epidemiology, resistance and pathology. The Planter, 87(1024): 515-526.

COOPER, R M; KEMP, B; DAY, R; GOMEZ VASQUEZ, $R$ and BEECHING, J R (2001). Pathogenicity and resistance in Xanthomonas blight of cassava. Pathogenic Bacteria (De Boer, S H ed). Dortrecht: Kluwer. p. 319-323

DEWICK, P M (2002). The shikimate pathway: aromatic amino acids and phenylpropanoids. Medicinal Natural Products. John Wiley \& Sons, Ltd. p. 121-166.

DIABATE, S; FRANQUEVILLE, H; ADON, B; COULIBALY, O A and AKE, S (2009). The role of phenolic compounds in the determination of wilt disease tolerance of oil palm (Elaeis guineensis Jacq). African J. Biotechnology, 8: 5679-5690.

DURAND-GASSELIN, T; ASMADY, H; FLORI, A; JACQUEMARD, J C; HAYUN, Z; BRETON, F and DE FRANQUEVILLE, H (2005). Possible sources of genetic resistance in oil palm (Elaeis guineensis Jacq.) to basal stem rot caused by G. boninense - prospects for future breeding. Mycopathologia, 159: 93-100. 
DZULKAFLI, S B; ABRIZAH, O; RAMLI, U S; TAHIR, N I; SYAHANIM, S; NURAZAH, Z; MOHAMAD ARIF, A M; IDRIS, A S and MOHD DIN, A (2015). Identification of chelidonic acid in oil palm spear leaf artificially infected with Ganoderma boninense using liquid chromatography mass spectrometry. Proc. of the PIPOC 2015 International Palm Oil Congress. p. 386-391.

FERNIE, A R and KEURENTJES, J J B (2011). Genetics, genomics and metabolomics. Annual Plant Reviews Volume 43: Biology of Plant Metabolomics (Hall, R D ed.). Wiley-Blackwell, Oxford, UK.

FERRACANE, R; GRAZIANI, G; GALLO, M; FOGLIANO, V and RITIENI, A (2010). Metabolic profile of the bioactive compounds of burdock (Arctium lappa) seeds, roots and leaves. J. Pharmaceutical and Biomedical Analysis, 51: 399-404.

FERNIE, A R and SCHAUER, N (2009). Metabolomics-assisted breeding: a viable option for crop improvement? Trends in Genetics, 25(1): 39-48.

FONGUIMGO, T F; HANAFI, $\mathrm{M}$ M; IDRIS, A S; SAHEBI, $M$ and SYED-OMAR, S R (2015). Comparative study of lignin in roots of different oil palm progenies in relation to Ganoderma basal stem rot disease. J. Oil Palm Res. Vol. 27(2): 128-134.

FORLANI, G (2010). Differential in vitro responses of rice cultivars to Italian lineages of the blast pathogen Pyricularia grisea. 2. Aromatic biosynthesis. J. Plant Physiology, 167: 928-932.

FRANCL, L J (2007). The disease triangle: a plant pathological paradigm revisited. The Plant Health Instructor. DOI: 10. 1094/ PHI-T-2001-0517-01.

FRASER, C M and CHAPPLE, C (2011). The phenylpropanoid pathway in Arabidopsis. The Arabidopsis Book. p. 1-19.

GENG, L; SUN, H; YUAN, Y; LIU, Z; CUI, Y; BI, $K$ and CHEN, $X$ (2013). Discrimination of raw and vinegar-processed GenkwaFlos using metabolomics coupled with multivariate data analysis: a discrimination study with metabolomics coupled with PCA. Fitoterapia, 84: 286-294.

GIBERTIA, S; BERTEAB, C M; NARAYANAB, R; MAFFEIB, M E and FORLANI, G (2012). Two phenylalanine ammonia lyase isoforms are involved in the elicitor-induced response of rice to the fungal pathogen Magnaporthe oryzae. J. Plant Physiology, 169: 249-254.

GONG, L; CHEN, W; GAO, Y; LIU, X; ZHANG, H; XU, C; YU, S; ZHANG, Q and LUO, J (2013). Genetic analysis of the metabolomics exemplified using a rice population. Proc. of the National Academy of Sciences of the USA, 110(50): 20320-20325.

HILL, C B; TAYLOR, J D; EDWARDS, J; MATHER, D; LANGRIDGE, P; BACIC, A and ROESSNER, U (2015). Detection of QTL for metabolic and agronomic traits in wheat with adjustments for variation at genetic loci that affect plant phenology. Plant Science, 233: 143-154.

HOLMES, E and ANTTI, H (2002). Chemometric contributions to the evolution of metabonomics: mathematical solutions to characterising and interpreting complex biological NMR spectra. Analyst, 127: 1549-1557.

HONG, J; YANG, L; ZHANG, D and SHI, J (2016). Plant metabolomics: an indispensable system biology tool for plant science. International J. Molecular Sciences, 17(6): 1-16.

IDRIS, A S; KUSHAIRI, A; ISMAIL, S and ARIFFIN D (2004a). Selection of partial resistance in oil palm progenies to Ganoderma basal stem rot. J. Oil Palm Res. Vol. 16: 12-18.

IDRIS, A S; ISMAIL, S; ARIFFIN, D and AHMAD, $\mathrm{H}$ (2004b). Prolonging the productive life of Ganoderma-infected palms with hexaconazole. MPOB Information Series No. 214: 4 pp.

JEFFERY DAIM, L D; OOI, T E; ITHNIN, N; MOHD YUSOF, H; KULAVEERASINGAM, H; ABDUL MAJID, N and KARSANI, S A (2015). Comparative proteomic analysis of oil palm leaves infected with Ganoderma boninense revealed changes in proteins involved in photosynthesis, carbohydrate metabolism, and immunity and defense. Electrophoresis, 36(15): 1699-1710.

KIM, M; LIM, J H; AHN, C S; PARK, K; KIM, G T; KIM, W T and PAI, H S (2006). Mitochondriaassociated hexokinases play a role in the control of programmed cell death in Nicotiana benthamiana. Plant Cell, 18: 2341-2355.

KIRAN KUMAR, S J and GOWDA, S R (2016). Acetylcholinesterase activity from plant extracts and analysis by GC-MS and autodock. World J. Pharmacy and Pharmaceutical Sciences, 5(9): 1829-1854.

$\mathrm{KOCH}, \mathrm{K}$ (2004). Sucrose metabolism: regulatory mechanism and pivotal roles in sugar sensing and plant development. Current Opinion in Plant Biology, 7: 235-246.

LATTANZIO, V; LATTANZIO, $\mathrm{V} \mathrm{M} \mathrm{T}$ and CARDINALI, A (2006). Role of phenolics in the 
resistance mechanisms of plants against fungal pathogens and insects. Phytochemistry: Advances in Research (Imperato, F ed.). Research Signpost, India. p. 23-67.

LINDON, J C; HOLMES, E and NICHOLSON, J K (2001). Pattern recognition methods and applications in biomedical magnetic resonance. Progress in Nuclear Magnetic Resonance Spectroscopy, 39: 1-40.

MA, C; DASTMALCHI, K; FLORES, G; WU, $S$ B; PEDRAZA-PENALOSA, P; LONG, C and KENNELLY, E J (2013). Antioxidant and metabolite profiling of North American and neotropical blueberries using LC-TOF-MS and multivariate analyses. J. Agricultural and Food Chemistry, 61: 35483559 .

MATSUDA, F;OKAZAKI, Y;OIKAWA, A; KUSANO, M; NAKABAYASHI, R; KIKUCHI, J; YONEMARU, J I; EBANA, K; YANO, M and SAITO, K (2012). Dissection of genotype-phenotype associations in rice grains using metabolome quantitative trait loci analysis. Plant J., 70: 624-636.

MC DONALD, B A and LINDE, C (2002). Pathogen population genetics, evolutionary potential and durable resistance. Annual Review of Phytopathology, 40: 349-379.

MILLER, R N G; HOLDERNESS, M; BRIDGE, P D; CHUNG, G F and ZAKARIA, M H (1999). Genetic diversity of Ganoderma in oil palm plantings. Plant Pathology, 48: 595-603.

MORKUNAS, I and RATAJCZAK, L (2014). The role of sugar signalling in plant defense responses against fungal pathogens. Acta Physiologiae Plantarum, 36: 1607-1619.

MORKUNAS, I; NAROZNA, D; NOWAK, $\mathrm{W}$; SAMARDAKIEWICZ, $\mathrm{W}$ and REMLEINSTAROSTA, D (2011). Cross-talk interactions of sucrose and Fusarium oxysporum in the phenylpropanoid pathway and the accumulation and localization of flavonoids in embryo axes of yellow lupine. J. Plant Physiology, 168: 424-433.

MPOB (2016). Production of Oil Palm Products 2016. Economics and Industry Development Division. Ministry of Plantation Industries and Commodities. http: / / bepi.mpob.gov.my / index.php / en / statistics / production / 168-production-2016/747production-of-oil-palm-products-2016.html)

NG, L K; LAFONTAINE, P and VANIER, M (2004). Characterization of cigarette tobacco by direct electrospray ionization-ion trap mass spectrometry (ESI-ITMS) analysis of the aqueous extract - a novel and simple approach. J. Agricultural and Food Chemistry, 52: 7251-7257.

NURAZAH, Z; IDRIS, A S; KUSHAIRI, A and RAMLI, U S (2013). Metabolite profiling of oil palm towards understanding basal stem rot (BSR) disease. J. Oil Palm Res. Vol. 25 (4): 58-71.

NUSAIBAH, $S$ A; SITI NOR AKMAR, A; MOHAMAD PAUZI, Z; IDRIS, A S and MEON, S (2011). Detection of phytosterols in G. boninenseinfected oil palm seedlings through GC-MS analysis. J. Oil Palm Res. Vol. 23: 1069-1077.

OIL WORLD ANNUAL (2016). Chapter 2: 17 Oils and fats. Waning production of major vegetable oils creates large deficit this season. Oil World Annual 2016. Vol. 1, ISTA Mielke GmbH, Germany. 11 pp.

PATERSON, R R M; MEON, S and LIMA, N (2009). The feasibility of producing oil palm with altered lignin content to control Ganoderma disease. J. Phytopathology, 157: 649-656.

PATERSON, R R M (2008). Fungal enzyme inhibitors as pharmaceuticals, toxins and scourge of PCR. Current Enzyme Inhibition, 4: 45-59.

PLINE, $\mathrm{W}$ A; WILCUT, J W; DUKE, $\mathrm{S}$ O; EDMISTEN, K L and WELLS, R (2002). Tolerance and accumulation of shikimic acid in response to glyphosate applications in glyphosate-resistant and non-glyphosate-resistant cotton (Gossypium hirsutum L.). J. Agricultural and Food Chemistry, 50: 506-512.

PUSHPA, D; YOGENDRA, K N; GUNNAIAH, R; KUSHALAPPA, A C and MURPHY, A (2014). Identification of late blight resistance-related metabolites and genes in potato through nontargeted metabolomics. Plant Molecular Biology Reporter, 32: 584-595.

RAVICHANDRA, N G (2013). Fundamentals of Plant Pathology. PHI Learning Pvt. Ltd, New Delhi.

ROLLAND, F; BAENA-GONZALEZ, E and SHEEN, J (2006). Sugar sensing and signalling in plants: conserved and novel mechanisms. Annual Review of Plant Biology, 57: 675-709.

ROUTABOUL, J M; DUBOS, C; BECK, G; MARQUIS, C; BIDZINSKI, P; LOUDET, O and LEPINIEC, L (2012). Metabolite profiling and quantitative genetics of natural variation for flavonoids in Arabidopsis. J. Experimental Botany, 63: 3749-3764.

SAITO, K and MATSUDA, F (2010). Metabolomics for functional genomics, system biology and 
biotechnology. Annual Review of Plant Biology, 61: 463-489.

SUNDRAM, S (2013). The effects of Trichoderma in surface mulches supplemented with conidial drenches in the disease development of Ganoderma basal stem rot in oil palm. J. Oil Palm Res. Vol. 25(3): 314-325.

SUNDRAM, S; ABDULLAH, F; AHMAD, ZAM and YUSUF, U K (2008). Efficacy of single and mixed treatments of Trichoderma harzianum as biocontrol agents of Ganoderma basal stem rot in oil palm. J. Oil Palm Res. Vol. 20: 470-483.

SUSANTO, A; SUDHARTO, P $\mathrm{S}$ and PURBA, R $Y$ (2005). Enhancing biological control of basal stem rot disease (Ganoderma boninense) in oil palm plantations. Mycopathologia, 159: 153-157.

SYAHANIM, S; ABRIZAH, O; MOHAMAD ARIF, A M; IDRIS, A S and MOHD DIN, A (2013). Identification of differentially expressed proteins in oil palm seedlings artificially infected with Ganoderma: a proteomics approach. J. Oil Palm Res. Vol. 25(3): 298-304.

TAYLOR, V F; MARCH, R E; LONGERICH, H P and STADEY, C J (2005). A mass spectrometric study of glucose, sucrose and fructose using an inductively coupled plasma and electrospray ionization. International J. Mass Spectrometry, 243: 71-84.

TOUBIANA, D; FERNIE, A R; NIKOLOSKI, Z and FAIT, A (2013). Network analysis: tackling complex data to study plant metabolism. Trends in Biotechnology, 31: 29-36.

VERDIER, V; RESTREPO, S; BOHER, B; NICOLE, M; GEIGER, J P; ALVAREZ, E and BONIERBALE, M (1997). Cassava bacterial blight: recent achievement in understanding the disease. African J. Root and Tuber Crops, 2: 64-68.

WERTH, M T; HALOUSKA, S; SHORTRIDGE, M D; ZHANG B and POWERS R (2010). Analysis of metabolomic PCA data using tree diagrams. Analytical Biochemistry, 399: 58-63.

WITTSTOCK, U and GERSHENZON, J (2002). Constitutive plant toxins and their role in defense against herbivores and pathogens. Current Opinion in Plant Biology, 5: 1-8.

WOLF, S; SCHMIDT, S; MULLER-HANNEMANN, $\mathrm{M}$ and NEUMAN, S (2010). In silico fragmentation for computer assisted of metabolite spectra. BMC Bioinformatics, 11: 148-159.

WONG, C L; BONG, J F C and IDRIS, A S (2012). Ganoderma species associated with basal stem rot disease of oil palm. American J. Applied Sciences, 9: 879-885.

WU, J; YU, H; DAI, H; MEI, W; HUANG, X; ZHU, $S$ and PENG, M (2012). Metabolite profiles of rice cultivars containing bacterial blight-resistant genes are distinctive from susceptible rice. Acta Biochimica et Biophysica Sinica, 44: 650-659. 